\title{
Water Efflux in Red Blood Cells of Sickle Cell Patients under Spontaneous Deoxygenation
}

\section{Manuel Arsenio Lores Guevara ${ }^{*}$, Yulianela Mengana Torres ${ }^{1}$, Juan Carlos García Naranjoㄹ, Andrés Ramírez Aguilera1, Lidia Clara Suárez Beyrio², María Altagracia Marichal Felue², Teresa Simón Brada², Jan Philippé ${ }^{3}$}

${ }^{1}$ Centro de Biofísica Médica, Santiago de Cuba, Cuba

${ }^{2}$ Hospital General "Juan Bruno Zayas Alfonso", Santiago de Cuba, Cuba

${ }^{3}$ Department of Clinical Chemistry, Immunology and Microbiology, Ghent University, Ghent, Belgium

Email:^manuel.lores@cbiomed.cu

How to cite this paper: Guevara, M.A.L., Torres, Y.M., Naranjo, J.C.G., Aguilera, A.R., Beyrio, L.C.S., Felue, M.A.M., Brada, T.S. and Philippé, J. (2016) Water Efflux in Red Blood Cells of Sickle Cell Patients under Spontaneous Deoxygenation. Journal of Biosciences and Medicines, 4, 152-161. http://dx.doi.org/10.4236/jbm.2016.412019

Received: October 14, 2016

Accepted: December 13, 2016

Published: December 16, 2016

Copyright $\odot 2016$ by authors and Scientific Research Publishing Inc. This work is licensed under the Creative Commons Attribution International License (CC BY 4.0).

http://creativecommons.org/licenses/by/4.0/

\begin{abstract}
The water transport through Red Blood Cells (RBC) membrane has been previously studied in Sickle Cell Disease (SCD) using oxygenated RBC or under complete deoxygenation. In this work, the water efflux in RBC of sickle cell patients was studied under spontaneous deoxygenation conditions. With that purpose, a magnetic resonance method was used to evaluate the water exchange time $\left(\tau_{e}\right)$ and the permeability through the erythrocyte membrane $(P)$ measuring the spin-spin relaxation time $\left(T_{2}\right)$ in doped and non-doped RBC. Carr-Purcell-Meiboon-Gill (CPMG) pulse sequence was used to measure $T_{2}$ in a magnetic resonance console coupled to one homogeneous magnet system $(0.095 \mathrm{~T})$. An increase of the water transport in RBC from sickle cell patients was observed and characterized with a $\tau_{e}$ value of $15.2 \pm 0.8$ ms. The abnormal activation of the $P_{\text {sickle }}$, Gardos, and potassium chloride cotransporter channels starting from deoxygenation, as well as, the possible appearance of new pores due to the increase of the hemoglobin-membrane interaction, are suggested to explain this abnormal transport phenotype. The change of the water volume to surface ratio (V/S) in the sickle cells is also suggested to be considered in $P$ calculation under deoxygenation. The results obtained in this work increase the fundamental knowledge about molecular mechanism involved in SCD and could be useful in the development of new methods for diagnostic and treatment evaluation.
\end{abstract}

\section{Keywords}

Red Blood Cells, Water Permeability, Nuclear Magnetic Relaxation, Sickle Cell Disease

\section{Introduction}

After one century, SCD is still an important worldwide health problem without a final 
solution [1]. Its complexity, genetic origin [2] and the different molecular processes involved in its pathophysiology [3] have contributed to this situation. The presence of an abnormal hemoglobin ( $\mathrm{HbS}$ ) inside the RBC, causing a polymerization process under deoxygenation, is recognized as the molecular process contributing most to the pathogenesis of SCD [4], and for this reason many efforts have been made in relation to its study [5] [6] [7] [8] [9]. Nevertheless, the deoxygenation also causes cell damage, dehydration and shrinking [10].

Different membrane abnormalities have been documented in RBC from sickle cell patients [11]: loss of lipid bilayer asymmetry, altered rate of phosphatidylcholine flipflop, abnormal spectrin-actin skeleton, as well as, defective association between ankyrin and spectrin in situ on sickle cell inside out vesicles. These cause functional abnormalities as an abnormal transport phenotype [11] [12]: increased influx of calcium, reduced efflux permeability to non-electrolytes as glycerol and ethylene glycol and net loss of monovalent cations. Specially, the net loss of monovalent cations has been directly related with direct cellular dehydration because of the cellular response to maintain the osmotic equilibrium [12].

The water transport in RBC has been widely studied before [13]-[18]. Especially, the water efflux and influx through the membrane of RBC from sickle cell patients has been studied in oxygenated erythrocytes [19] and in cells under total deoxygenation [20], however, no studies under spontaneous deoxygenation have been performed. On the other hand, after deoxygenation, no values of $\tau_{e}$ and no proper values of $P$ have been reported.

The deoxygenation pattern (deoxygenation \% and speed) defines the HbS polymerization, as well as, the RBC shape change [2] [4]. In this work, we study $\tau_{e}$ after HbS polymerization under spontaneous deoxygenation conditions. Different molecular mechanisms are considered to explain the observed behaviour, and the necessity of an adequate evaluation of the $V / S$ to calculate $P$ in sickle cells, after deoxygenation, is discussed.

\section{Materials and Methods}

After the approval of the hospital ethical committee, and the obtaining of the informed consent, samples of RBCA (containing adult normal hemoglobin, $\mathrm{HbA}$ ) and RBCS (containing $\mathrm{HbS}$ ) were obtained [5]. Whole blood samples were obtained by venipuncture and immediately heparinized. After removing the plasma and leukocytes, RBC were washed three times with phosphate buffered saline (PBS, pH 7.4, Sigma Chemicals Co.) [5] [6] [7] [8] [9]. Supernatants were removed by centrifugation (500 g, $10 \mathrm{~min}$ ) and decanting. The obtained washed RBC were resuspended (Hematocrit $45 \%$, PBS $(\mathrm{pH} 7.4), 0.5 \%$ of BSA) and one portion was centrifuged $\left(1000 \mathrm{~g}, 30 \mathrm{~min}, 25^{\circ} \mathrm{C}\right)$ eliminating the supernatant to obtain packed RBC. $500 \mu \mathrm{l}$ of packed RBC were taken and $T_{2}$ for this sample was measured $\left(T_{2 a}\right)$.

$300 \mu \mathrm{l}$ of resuspended RBC were mixed with $600 \mu \mathrm{l}$ of the manganese chloride stock solution $\left(\mathrm{MnCl}_{2}(\mathrm{aq})\right)$ to obtain a final concentration of $2.5 \mathrm{mM}$. $500 \mu \mathrm{l}$ of doped $\mathrm{RBC}$ 
were taken and $T_{2}$ for this sample was measured $\left(T_{2 d}\right)$.

Starting from the measured values of $T_{2 a}$ and $T_{2 d}, \tau_{e}$ and $P$ were calculated as follows [13]:

$$
\begin{gathered}
\frac{1}{\tau_{e}}=\frac{1}{T_{2 d}}-\frac{1}{T_{2 a}} \\
P=\frac{V}{S} \cdot \frac{1}{\tau_{e}}
\end{gathered}
$$

where $V\left(0.63 \times 10^{-10} \mathrm{~cm}^{3}\right)$ and $S\left(1.42 \times 10^{-6} \mathrm{~cm}^{2}\right)$ are the water volume inside the RBC and the surface of the RBC, respectively. $V / S=4.4 \times 10^{-5} \mathrm{~cm}$.

The magnetic resonance measurements were performed in a magnetic resonance console (MARAN DRX, Oxford Instruments, UK). $T_{2}$ was measured using CPMG pulse sequence with a resonance frequency of $4.0353 \mathrm{MHz}$ (homogeneous permanent magnet, $B_{0}=0.095 \mathrm{~T}$ ), 10 and $20 \mu$ s for $90^{\circ}$ and $180^{\circ}$ pulses respectively, 128 scans, $50 \%$ for the RF power amplifier and the receiver gains, $3 \mathrm{~s}$ of relaxation delay and echo time of $0.2 \mathrm{~ms}$ (doped RBC) and $2 \mathrm{~ms}$ (packed RBC).

A student's test (t-test) was performed to compare main values with $\alpha=0.05$.

\section{Results and Discussion.}

The values of $T_{2 d}, \tau_{e}$ and $P$ in oxygenated RBCA were measured for two temperature values $\left(25^{\circ} \mathrm{C}\right.$ and $29^{\circ} \mathrm{C}$ ) (see Table 1 ).

The $\tau_{e}$ and $P$ values for RBCA water efflux, shown in Table 1, are coherent with previous reports in the literature $\left(\tau_{e}=(9.8-14.0) \mathrm{ms} ; P=(3.3-4.7) \times 10^{-3} \mathrm{cms}^{-1}\right)$ [16]. The independence with the temperature is due to the activation energy characterizing

Table 1. $T_{2 d}, \tau_{e}$ and $P$ values corresponding to oxygenated RBCA for two temperature values $\left(25^{\circ} \mathrm{C} \pm 1^{\circ} \mathrm{C}\right.$ and $\left.29^{\circ} \mathrm{C} \pm 1^{\circ} \mathrm{C}\right)$.

\begin{tabular}{ccccc}
\hline Individuals & $T_{2 d}(\mathrm{~ms})$ & $\tau_{e}(\mathrm{~ms})$ & $P\left(10^{-3} \mathrm{cms}^{-1}\right)$ & $T\left({ }^{\circ} \mathrm{C}\right)$ \\
\hline $\mathbf{1}$ & $9.93 \pm 0.53$ & $12.00 \pm 0.23$ & $3.70 \pm 0.18$ & $29 \pm 1$ \\
$\mathbf{2}$ & $11.67 \pm 0.76$ & $13.00 \pm 0.46$ & $3.30 \pm 0.16$ & $29 \pm 1$ \\
$\mathbf{3}$ & $11.89 \pm 0.94$ & $13.7 \pm 1.2$ & $3.25 \pm 0.29$ & $29 \pm 1$ \\
$\mathbf{4}$ & $10.60 \pm 0.50$ & $11.30 \pm 0.67$ & $3.92 \pm 0.20$ & $29 \pm 1$ \\
$\mathbf{5}$ & $11.83 \pm 0.63$ & $12.80 \pm 0.84$ & $3.40 \pm 0.22$ & $29 \pm 1$ \\
$\mathbf{6}$ & $11.02 \pm 0.80$ & $12.19 \pm 0.75$ & $3.60 \pm 0.18$ & $29 \pm 1$ \\
$\mathbf{7}$ & $14.75 \pm 0.69$ & $16.30 \pm 0.84$ & $2.68 \pm 0.13$ & $29 \pm 1$ \\
$\mathbf{8}$ & $12.87 \pm 0.50$ & $13.93 \pm 0.58$ & $3.16 \pm 0.13$ & $29 \pm 1$ \\
$\mathbf{9}$ & $13.71 \pm 0.96$ & $15.0 \pm 1.1$ & $2.94 \pm 0.21$ & $29 \pm 1$ \\
10 & $11.28 \pm 0.40$ & $11.99 \pm 0.42$ & $3.67 \pm 0.13$ & $25 \pm 1$ \\
11 & $12.16 \pm 0.55$ & $13.32 \pm 0.66$ & $3.31 \pm 0.16$ & $25 \pm 1$ \\
12 & $14.98 \pm 0.43$ & $16.47 \pm 0.53$ & $2.67 \pm 0.01$ & $25 \pm 1$ \\
13 & $14.14 \pm 0.60$ & $15.21 \pm 0.53$ & $2.89 \pm 0.10$ & $25 \pm 1$ \\
Main values & $12.37 \pm 1.60$ & $13.6 \pm 1.6$ & $3.27 \pm 0.39$ & - \\
\hline
\end{tabular}


the process $\left(E_{a}=26 \mathrm{~kJ} \cdot \mathrm{mol}^{-1}\right)[18]$ and its influence in Equation (3).

$$
\tau_{e}=\tau_{e 0} \exp \left(-\frac{E_{a}}{K T}\right)
$$

$\tau_{e 0}, T$ and $K$ are the initial water exchange time, the absolute temperature and the Boltzman constant, respectively.

The $P$ values in oxygenated and spontaneously deoxygenated RBCA $\left(24 \mathrm{~h}, 36^{\circ} \mathrm{C}, 50 \%\right.$ of deoxygenation) are shown in Figure 1. Because of the deoxygenation inhibits the $\mathrm{KCC}\left(\mathrm{K}^{+}\right.$and $\mathrm{Cl}^{-}$cotransporter) channel activation in RBCA [12], causing $\tau_{e}$ increases, these cells have a reduced $P$ values after spontaneous deoxygenation. It was not taken into account and/or discussed in previous results [20].

The values of $T_{2 d}, \tau_{e}$ and $P$ in oxygenated RBCS are summarized in Table 2. $P$

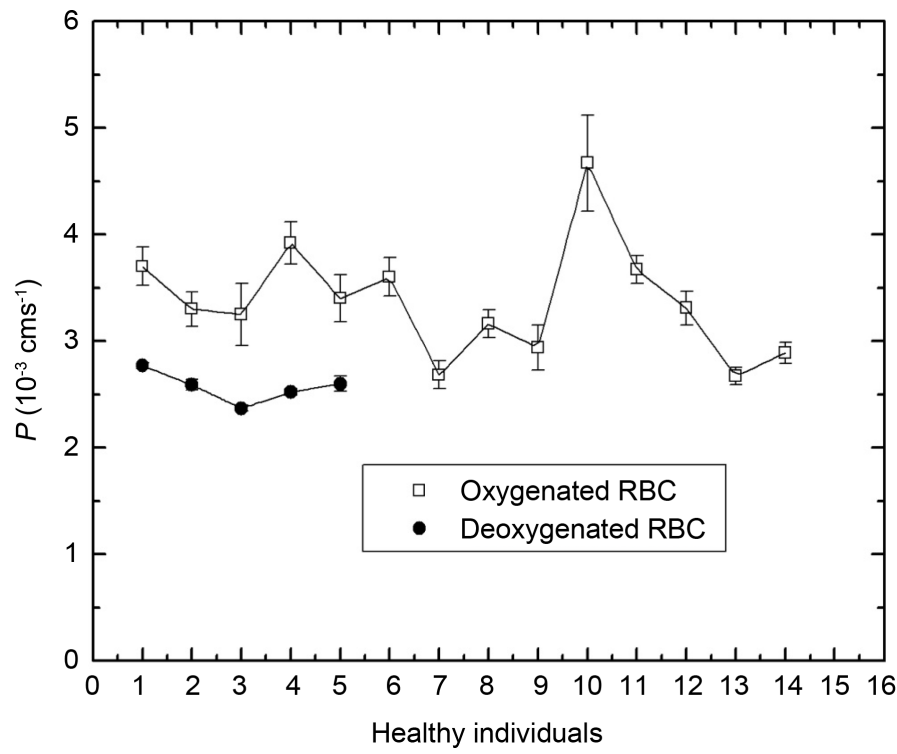

Figure 1. Efflux water permeability in oxygenated (100\% of oxygenation) and spontaneously deoxygenated (50\% of deoxygenation) RBC from healthy individuals. Red blood cells have intracellular concentrations and $P$ was determined starting from $\tau_{e}$ and $V / S$ ratio (Equation (2)). $\tau_{e}$ was measured using the $T_{2}$ values of doped $\left(2.5 \mathrm{mM} \mathrm{MnCl}_{2 \text { (aq) }}\right)$ and not doped $\mathrm{RBC}$ samples (Equation (1)). $T_{2}$ was measured using CPMG.

Table 2. $T_{2 d}, \tau_{e}$ and $P$ values in oxygenated RBCS.

\begin{tabular}{ccccc}
\hline Sickle Cell patient & $T_{2 d}(\mathrm{~ms})$ & $\tau_{e}(\mathrm{~ms})$ & $P\left(10^{-3} \mathrm{cms}^{-1}\right)$ & $T\left({ }^{\circ} \mathrm{C}\right)$ \\
\hline $\mathbf{1}$ & $16.01 \pm 0.80$ & $18.7 \pm 1.2$ & $2.35 \pm 0.16$ & $29 \pm 1$ \\
$\mathbf{2}$ & $17.34 \pm 0.30$ & $20.3 \pm 1.1$ & $2.16 \pm 0.15$ & $29 \pm 1$ \\
$\mathbf{3}$ & $21.71 \pm 0.70$ & $26 \pm 1$ & $1.69 \pm 0.12$ & $29 \pm 1$ \\
$\mathbf{4}$ & $17.16 \pm 0.96$ & $20.3 \pm 1.3$ & $2.17 \pm 0.14$ & $29 \pm 1$ \\
$\mathbf{5}$ & $16.27 \pm 0.96$ & $19.5 \pm 1.3$ & $2.26 \pm 0.16$ & $29 \pm 1$ \\
$\mathbf{6}$ & $18.84 \pm 0.88$ & $23.2 \pm 1.3$ & $1.89 \pm 0.11$ & $29 \pm 1$ \\
$\mathbf{7}$ & $15.4 \pm 1.1$ & $18.2 \pm 1.5$ & $2.43 \pm 0.21$ & $29 \pm 1$ \\
Main values & $17.5 \pm 2.1$ & $20.8 \pm 2.7$ & $2.13 \pm 0.26$ & $29 \pm 1$ \\
\hline
\end{tabular}


decreases $\left((2.13 \pm 0.26) \times 10^{-3} \mathrm{cms}^{-1}\right)$ and $\tau_{e}$ increases $\left(\tau_{e}=20.89 \pm 2.77 \mathrm{~ms}\right)$ if compared with the values obtained for healthy individuals $\left(P=(3.27 \pm 0.39) \times 10^{-3}\right.$ $\mathrm{cms}^{-1}$ and $\tau_{e}=13.63 \pm 1.67 \mathrm{~ms}$ ) (see Figure 2).

The increase in $\tau_{e}$ and $P$ reduction in oxygenated RBCS, compared with healthy individuals, match with previous reports $\left(P=(1.61 \pm 0.39) \times 10^{-3} \mathrm{cms}^{-1}\right.$ and $\tau_{e}=29.2 \pm$ $7.3 \mathrm{~ms}$ ) [19], and are closely related to:

- The lipid peroxidation in the lipid bilayer.

- The hemoglobin interaction with membrane Band 3 protein.

- The oxidation of Band 3 sulfhydryl groups in the $15 \mathrm{kDa}$ transmembrane fragment.

Because of simple diffusion only supports the $10 \%$ of the water transport through RBC membrane, the lipid peroxidation in the lipid bilayer cannot explain the observed $P$ reduction in $34 \%$. The sulfhydryl group oxidation is caused by the spontaneous generation of oxygen radicals and has been considered as the main contribution to $P$ reduction [19]. The hemoglobin-membrane interaction is established with the Band 3 protein, at the same position as the main pore ( $4.5 \AA$ ) for water transport in RBC membrane; and, therefore, could cause an occlusion of this channel [20]. It has been demonstrated that this interaction is stronger in oxygenated sickle cell patient RBC than in cells from healthy controls [21]. As a consequence, the occlusion could contribute to the observed $P$ reduction in oxygenated RBCS.

The values of $T_{2 d}$ and $\tau_{e}$ in RBCS, under spontaneous deoxygenation, are summarized in Table 3.

The spontaneous deoxygenation decreases $\tau_{e}$ values $\left(\tau_{e}=15.2 \pm 1.0 \mathrm{~ms}\right)$ of the RBCS compared with the results obtained before deoxygenation ( $\tau_{e}=20.8 \pm 2.7 \mathrm{~ms}$ )

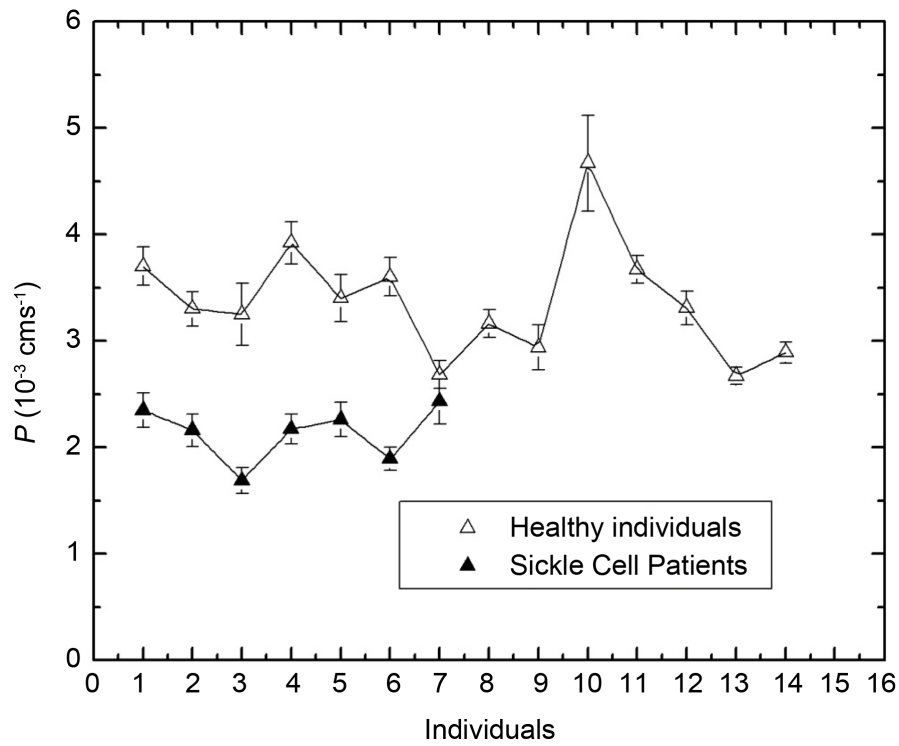

Figure 2. Efflux water permeability in oxygenated (100\% of oxygenation) RBC from healthy individuals and sickle cell patients. Red blood cells have intracellular concentrations and $P$ was determined starting from the $\tau_{e}$ and $V / S$ ratio (Equation (2)). $\tau_{e}$ was measured using the $T_{2}$ values of doped (2.5 $\mathrm{mM} \mathrm{MnCl} \mathrm{Maq}_{\text {(a) }}$ ) and not doped RBC samples (Equation (1)). $T_{2}$ was measured using CPMG. 
(see Figure 3).

Even though it is possible to find reports of the water transport for deoxygenated RBCS $\left(P=(1.58 \pm 0.06) \times 10^{-2} \mathrm{cms}^{-1}\right)[20]$, it does not affect the novelty of our results because in these experiments:

- The reported experimental values of efflux water permeability were 10 times higher than the established values for human RBC [16].

- Induced complete deoxygenation was employed to provoke the HbS polymerization (0.5 mM, sodium dithionite).

- The $\tau_{e}$ values are not reported.

The explanation of decreased $\tau_{e}$, as a consequence of the spontaneous deoxygenation, is related with the hemoglobin-membrane interaction and the activation of the $\mathrm{P}_{\text {sickle, }}$,

Table 3. Values of $T_{2 d}$ and $\tau_{e}$ in RBCS under spontaneous deoxygenation.

\begin{tabular}{cccc}
\hline Sickle Cell patient & $T_{2 d}(\mathrm{~ms})$ & $\tau_{e}(\mathrm{~ms})$ & $T\left({ }^{\circ} \mathrm{C}\right)$ \\
\hline $\mathbf{1}$ & $11.69 \pm 0.11$ & $14.63 \pm 0.17$ & $25 \pm 1$ \\
$\mathbf{2}$ & $11.32 \pm 0.24$ & $13.47 \pm 0.34$ & $25 \pm 1$ \\
$\mathbf{3}$ & $13.04 \pm 0.25$ & $16.04 \pm 0.39$ & $25 \pm 1$ \\
$\mathbf{4}$ & $13.26 \pm 0.49$ & $16.58 \pm 0.77$ & $25 \pm 1$ \\
$\mathbf{5}$ & $12.17 \pm 0.50$ & $14.92 \pm 0.76$ & $25 \pm 1$ \\
$\mathbf{6}$ & $12.57 \pm 0.16$ & $15.51 \pm 0.24$ & $25 \pm 1$ \\
$\mathbf{7}$ & $11.83 \pm 0.45$ & $14.39 \pm 0.67$ & $25 \pm 1$ \\
$\mathbf{8}$ & $13.3 \pm 2.1$ & $16 \pm 3$ & $25 \pm 1$ \\
Main values & $12.41 \pm 0.77$ & $15.2 \pm 1.0$ & $25 \pm 1$ \\
\hline
\end{tabular}

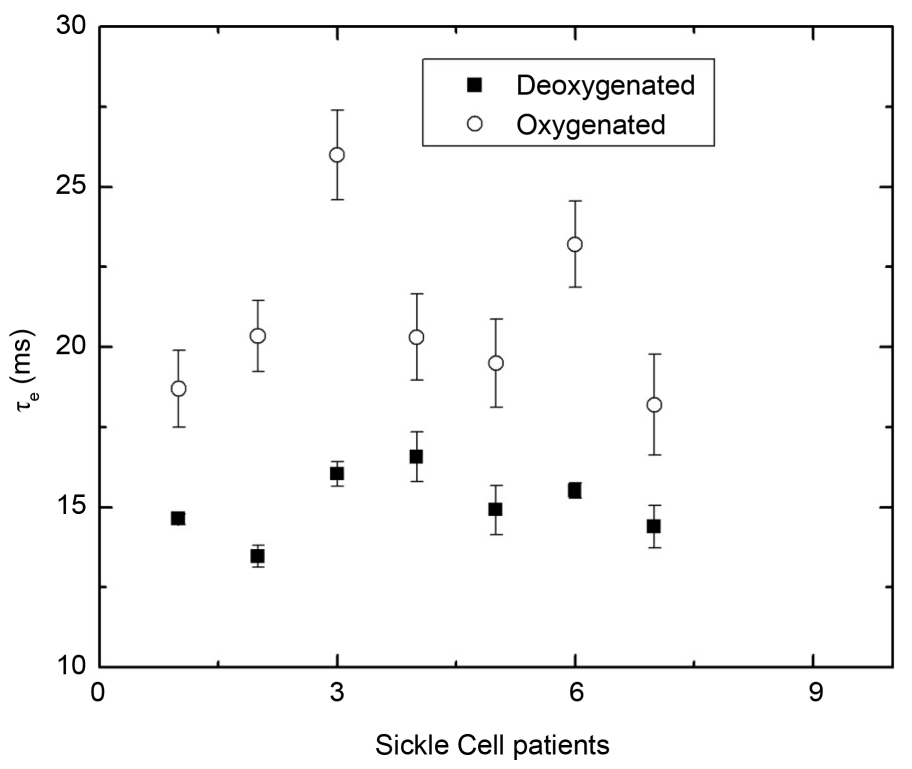

Figure 3. Water exchange time in oxygenated (100\% of oxygenation) and spontaneously deoxygenated (50\% of deoxygenation) RBC from sickle cell patients. Red blood cells have intracellular concentrations and $\tau_{e}$ was measured using the $T_{2}$ values of doped $\left(2.5 \mathrm{mM} \mathrm{MnCl} \mathrm{Maq}_{2}\right)$ and not doped RBC samples (Equation (1)). $T_{2}$ was measured using CPMG. 
Gardos, and KCC channels. The hemoglobin-membrane interaction could cause the appearance of pores starting from high order structure of the Band 3 protein [20]. We have previously demonstrated the increase of hemoglobin-membrane interaction with HbS polymerization under spontaneous deoxygenation conditions [22]. Now, we are strongly suggesting this increase could provoke the opening of new pores for the water efflux, which could explain the $\tau_{e}$ decrease after the agglutination process.

In RBCS, decreased oxygen partial pressure $\left(\mathrm{PO}_{2}\right)$ provokes the $P_{\text {sickle }}$ activation, causing a $\mathrm{K}^{+}$efflux, as well as, $\mathrm{Na}^{+}$and $\mathrm{Ca}^{2+}$ influx. When the $\mathrm{Ca}^{2+}$ concentration reaches a threshold, the Gardos Channels (about 150 per cells) are activated causing a fast $\mathrm{K}^{+}$ and $\mathrm{Cl}^{-}$efflux [12]. As a difference with RBCA, in the RBCS the deoxygenation inhibits the KCC channel until $\mathrm{PO}_{2}=40 \mathrm{mmHg}$, provoking it increases again when $\mathrm{PO}_{2}<40$ $\mathrm{mmHg}$ [12]. After $24 \mathrm{~h}$ of spontaneous deoxygenation $\left(\mathrm{PO}_{2}<40 \mathrm{mmHg}\right.$ [23], 50\% of deoxygenation) $\mathrm{KCC}$ is reactivated in our experiments contributing to the net ions loss. The efflux of ions is coupled with a water efflux to maintain the osmotic equilibrium. The cellular dehydration increases the HbS concentration, which facilitates the HbS polymerization, the increase in the hemoglobin-membrane interaction, and the RBC shrinking.

On the other hand, it is important to consider that we are determining $P$ (Equation (2)) for RBCA and RBCS using the same $V / S$ ratio, as usual in the literature [19]. We consider this is an adequate procedure in oxygenated RBCS taking into account that: the Mean Corpuscular Volume (MCV) and Surface Area $(S)$ do not have a statistically significant variation in these cells [24]-[29]. For deoxygenated RBCS is reported a MCV decreasing [30] [31] [32] [33] [34] and $S$ remains constant [31], which could change the $V / S$ ratio and affect the $P$ values. For this reason, in this work we are only reporting the $\tau_{e}$ values after deoxygenation for RBCS. To evaluate $P$, it is necessary to determine the $V / S$ behavior in RBCS after deoxygenation. It could be done by performing a magnetic resonance experiment which includes a magnetic field gradient, studying the water selfdiffusion coefficient behavior for short interpulse delay time in CPMG or stimulated echo pulse sequences [35]. Another way to measure $P$ is starting from the effective water self-diffusion coefficient measured in the RBC, as well as, in the extracellular and intracellular medium [35]. Starting from this last determination and measuring, in the same sample, the $\tau_{e}$ values using the method described in this work, it is also possible to determine $V / S$ using Equation (2). It will be the subject of forthcoming works.

Not separated variations in water transport have been found in density-separated cell fractions of RBCS [19] [20], for that reason our study has not considered it.

\section{Conclusion}

The HbS polymerization process, under spontaneous deoxygenation conditions, leads to an increase in the water transport through the RBC membrane from sickle cell patients, characterized by $\tau_{e}$ values of $15.2 \pm 0.8 \mathrm{~ms}$. The abnormal activation of the $P_{\text {sickle }}$, Gardos, and KCC channels starting from deoxygenation, as well as, the possible appearance of new pores due to the increased hemoglobin-membrane interaction could 
explain this abnormal transport phenotype. The results obtained in this work increase the fundamental knowledge about molecular mechanism involved in SCD and could be useful in the development of new methods for diagnostic and treatment evaluation.

\section{Acknowledgements}

This work has been supported by the Belgian Development Cooperation through VLIRUOS (Flemish Interuniversity Council-University Cooperation for Development) in the context of the Institutional University Cooperation program with Universidad de Oriente. The authors also want to thank the MRI RESEARCH CENTRE of the University of New Brunswick, Fredericton, Canada, for all the support received to finalize this work.

\section{References}

[1] (2014) Sickle-Cell Disease. Nature, 515, No. 7526.

[2] Schechter, A.N., Noguchi, C.T. and Rodgers, G.P. (1987) Sickle Cell Disease. In: Stamatoyannopoulos, G., Nienhuis, A.W., Leder, P. and Majerus, P.W., Eds., The Molecular Basis of Blood Diseases, Saunders, Philadelphia, PA, 179.

[3] Sergeant, G.R. (1997) Sickle Cell Disease. Oxford University Press, London.

[4] Eaton, W.A. and Hofrichter, J. (1987) Hemoglobin S Gelation and Sickle Cell Disease. Blood, 70, 1245

[5] Lores, M. and Cabal, C. (2005) Proton Magnetic Relaxation Process during the Polymerization of Hemoglobin S. Applied Magnetic Resonance, 28, 79.

https://doi.org/10.1007/BF03166995

[6] Lores, M., Cabal, C., Nascimento, O. and Gennaro, A.M. (2006) EPR Study of the Hemoglobin Rotational Correlation Time and Microviscosity during the Polymerization of Hemoglobin S. Applied Magnetic Resonance, 30, 121-128. https://doi.org/10.1007/BF03166986

[7] Cabrales, Y., Lores, M. and Machado, Y. (2008) Deuterium Magnetic Relaxation Process during the Polymerization of Hemoglobin S. Applied Magnetic Resonance, 33, 207. https://doi.org/10.1007/s00723-008-0074-z

[8] Lores, M., Balcom, B., Cabal, C., Cabrales, Y., Falcón, J., Fernández, A., García, J.C., López, N. and Álvarez, E. (2012) Estudios de Resonancia Magnética en Anemia de Hematíes Falciformes Revista Electrónica, automática y Comunicaciones, 33, 2.

[9] Lores, M., García, J.C., Mengana, Y. and Pereira, J. (2014) Hemoglobin S Polymerization Effect onWater Self-Diffusion Coefficient. Advances in Biological Chemistry, 4, 388-394. https://doi.org/10.4236/abc.2014.46044

[10] Virgilio, L., Lew, L. and Robert, M. (2005) Ion Transport Pathology in the Mechanism of Sickle Cell Dehydration. Physiological Reviews, 85, 179. https://doi.org/10.1152/physrev.00052.2003

[11] Hebbel, R.P. (1991) Beyond Hemoglobin Polymerization: The Red Blood Cell Membrane and Sickle Disease Pathophysiolog. Blood, 77, 214-237.

[12] Gibson, J.S. and Ellory, J.C. (2002) Membrane Transport in Sickle Cell Disease. Blood Cells, Molecules, and Diseases, 28, 303-314. https://doi.org/10.1006/bcmd.2002.0515

[13] Conlon, T. and Outhred, R. (1972) Water Diffusion Permeability of Erythrocytes Using an NMR Technique. Biochimica et Biophysica Acta, 288, 354-361. https://doi.org/10.1016/0005-2736(72)90256-8 
[14] Fabry, M.E. and Eisenstadt, M. (1975) Water Exchange between Red Cells and Plasma. Measurement by Nuclear Magnetic Relaxation. Biophysical Journal, 15, 1101-1110. https://doi.org/10.1016/S0006-3495(75)85886-3

[15] Morariu, V.V., Ionescu, M.S., Frangopol, M., Grosescu, R., Lupu, M. and Frangopol, P.T. (1985) Nuclear Magnetic Resonance Investigation of Human Erythrocytes in the Presence of Manganese Ions. Evidence for a Thermal Transition. Biochimica et Biophysica Acta, 815, 189-195. https://doi.org/10.1016/0005-2736(85)90288-3

[16] Herbst, M.D. and Goldstein, J.H. (1989) A Review of Water Diffusion Measurement by Nmr in Human Red Blood-Cells. American Journal of Physiology, 256, C1097-C1104.

[17] Chao, L.N. and Allan Butterfield, D. (1990) The Effects of the Extracellular Manganese Concentration and Variation of the Interpulse Delay Time in the CPMG Sequence on Water Exchange Time across Erythrocyte Membranes. Biochimica et Biophysica Acta, 1028, 245-250. https://doi.org/10.1016/0005-2736(90)90173-L

[18] Benga, G. (2013) Comparative Studies of Water Permeability of Red Blood Cells from Humans and over 30 Animal Species: An Overview of 20 Years of Collaboration with Philip Kuchel. European Biophysics Journal, 42, 33-46. https://doi.org/10.1007/s00249-012-0868-7

[19] Fung, L., Narasmhan, C., Lu, H.Z. and Westerman, M.P. (1989) Reduced Water Exchange in Sickle Cell Anemia Red Cells: A Membrane Abnormality. Biochimica et Biophysica Acta, 982, 167-172. https://doi.org/10.1016/0005-2736(89)90188-0

[20] Craescu, C.T., Cassoly, R., Galacteros, F. and Prehu, C. (1985) Kinetics of Water Transport in Sickle Cells. Biochimica et Biophysica Acta, 812, 811-815. https://doi.org/10.1016/0005-2736(85)90276-7

[21] Fung, L.W., Litvin, S.D. and Reid, T.M. (1983) Spin-Label Detection of Sickle HemoglobinMembrane Interaction at Physiological pH. Biochemistry, 22, 864-869. https://doi.org/10.1021/bi00273a024

[22] Falcón-Diéguez, J.E., Rodi, P., Lores, M. and Gennaro, A.M. (2010) Spin Label Studies of the Hemoglobin-Membrane Interaction during Sickle Hemoglobin Polymerization. Applied Magnetic Resonance, 38, 443-453. https://doi.org/10.1007/s00723-010-0138-8

[23] Lehninger, A.L. (1981) Bioquímica: Las bases moleculares de la estructura y función celular. 2nd Edition, Editorial Pueblo y Educación, Ciudad Habana, 150.

[24] Byun, H., Hillman, T.R., Higgins, J.M., Diez-Silva, M., Peng, Z., Dao, M., Dasari, R.R., Suresh, S. and Park, Y. (2012) Optical Measurement of Biomechanical Properties of Individual Erythrocytes from a Sickle Cell Patient. Acta Biomaterialia, 8, 4130-4138. https://doi.org/10.1016/j.actbio.2012.07.011

[25] Chien, S., Usami, S. and Bertles, J.F. (1970) Abnormal Rheology of Oxygenated Blood in Sickle Cell Anemia. Journal of Clinical Investigation, 49, 623-634. https://doi.org/10.1172/JCI106273

[26] Bertles, J.F. and Milner, P.F.A. (1968) Irreversibly Sickled Erythrocytes: A Consequence of the Heterogeneous Distribution of Hemoglobin Types in Sickle-Cell Anemia. Journal of Clinical Investigation, 47, 1731-1741. https://doi.org/10.1172/JCI105863

[27] Embury, S.H., Backer, K. and Glader, B.E. (1985) Mono-Valent Cation Changes in Sickle Erythrocytes-A Direct Reflection of Alpha-Globin Gene Number. Journal of Laboratory and Clinical Medicine, 106, 75-79.

[28] Embury, S.H., Oliver, M. and Kropp, J. (2014) The Beneficial Effect of $\alpha$ Thalassemia on Sickle cell Anemia (SCA) Is Related to Increased Membrane Redundancy. 27th Annual Meeting. The American society of hematology.

[29] Nash, G.B., Johnson, C.S. and Meiselman, H. (1984) Mechanical Properties of Oxygenated 
Red Blood Cells in Sickle Cell (HbSS) Disease. Blood, 63, 73-82.

[30] Dong, C., Chadwick, R.S. and Schechter, A.N. (1992) Influence of Sickle Hemoglobin Polymerization and Membrane Properties on Deformability of Sickle Erythrocytes in the Microcirculation. Biophysical Journal, 63, 774-783.

https://doi.org/10.1016/S0006-3495(92)81655-7

[31] Masys, D.R., Bromberg, P.A. and Balcerzak, S.P. (1974) Red Cells Shrink during Sickling. Blood, 44, 885-889.

[32] Canham, P.B. and Parkinson, D.R. (1970) The Area and Volume of Single Human Erythrocytes during Gradual Osmotic Swelling to Hemolysis. Canadian Journal of Physiology and Pharmacology, 48, 369-376. https://doi.org/10.1139/y70-059

[33] Lew, V.L. and Bookchin, R.M. (1991) Osmotic Effects of Protein Polymerization: Analysis of Volume Changes in Sickle Cell Anemia Red Cells Following Deoxy-Hemoglobin S Polymerization. Journal of Membrane Biology, 122, 55-67. https://doi.org/10.1007/BF01872739

[34] Diez-Silva, M., Dao, M., Han, J., Lim, C.T. and Suresh, S. (2010) Shape and Biomechanical Characteristics of Human Red Blood Cells in Health and Disease. MRS Bulletin, 35, 382388. https://doi.org/10.1557/mrs2010.571

[35] Latour, L.L., Svoboda, K., Mitra, P.P. and Sotak, C.H. (1994) Time-Dependent Diffusion of Water in a Biological Model System. Proceedings of the National Academy of Sciences of the United States of America, 91, 1229-1233. https://doi.org/10.1073/pnas.91.4.1229

\section{Submit or recommend next manuscript to SCIRP and we will provide best service} for you:

Accepting pre-submission inquiries through Email, Facebook, LinkedIn, Twitter, etc. A wide selection of journals (inclusive of 9 subjects, more than 200 journals)

Providing 24-hour high-quality service

User-friendly online submission system

Fair and swift peer-review system

Efficient typesetting and proofreading procedure

Display of the result of downloads and visits, as well as the number of cited articles

Maximum dissemination of your research work

Submit your manuscript at: http://papersubmission.scirp.org/

Or contact jbm@scirp.org 